Emblems of Eloquence 
The publisher gratefully acknowledges the generous contribution to this book provided by the Gladys Krieble Delmas Foundation. 


\title{
Emblems of Eloquence
}

\author{
Opera and Women's Voices \\ in Seventeenth-Century Venice
}

Wendy Heller

UNIVERSITY OF CALIFORNIA PRESS

Berkeley Los Angeles London 
University of California Press

Berkeley and Los Angeles, California

University of California Press, Ltd.

London, England

(C) 2003 by the Regents of the University of California

Library of Congress Cataloging-in-Publication Data

Heller, Wendy Beth.

Emblems of eloquence : opera and women's voices in seventeenthcentury Venice / Wendy Heller.

p. $\mathrm{cm}$.

Includes bibliographical references (p. ) and index.

ISBN 0-520-20933-8 (alk. paper)

1. Opera-1 $7^{\text {th }}$ century-Italy-Venice. 2. Women in opera.

I. Title.

ML210O.H45 2003

$782.1^{\prime}$ o82'o94531-dc2 1

2003001853

MN

Manufactured in the United States of America

$\begin{array}{llllllllll}12 & 11 & 10 & 09 & 08 & 07 & 06 & 05 & 04 & 03\end{array}$

$\begin{array}{llllllllll}10 & 9 & 8 & 7 & 6 & 5 & 4 & 3 & 2 & 1\end{array}$

The paper used in this publication meets the minimum requirements of ANSI/NISO Z39.48-1992 (R 1997) (Permanence of Paper). 
To my mother,

Betty Heller 
This page intentionally left blank 